\title{
THE ECONOMIC ANALYSIS OF WOOD AND CHARCOAL PRODUCTION BY Eucalyptus REFORESTATION IN NORTHWESTERN MINAS GERAIS
}

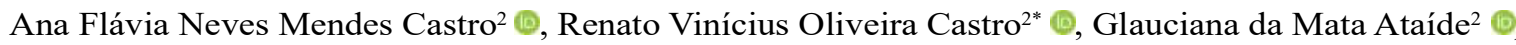

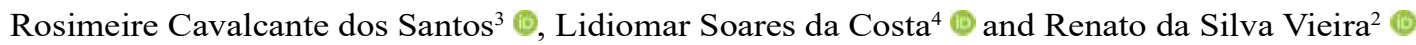

\footnotetext{
${ }^{1}$ Received on 14.08.2018 accepted for publication on 03.05.2019.

${ }^{2}$ Universidade Federal de São João Del-Rei, Departamento de Engenharia Florestal, Sete Lagoas, MG- Brasil. E-mail: <mendesafn@ hotmail.com>, <castrorvo@gmail.com>,<glaucianadamata@yahoo.com.br> and<rsvieira@ufsj.edu.br>.

${ }^{3}$ Universidade Federal do Rio Grande do Norte, Unidade Especializada em Ciências Agrárias,Macaíba, RN- Brasil . E-mail:

<meire_caico@yahoo.com.br>.

${ }^{4}$ Universidade Federal de Uberlândia, Instituto de Ciências Agrárias, Monte Carmelo, MG- Brasil. E-mail: <lidiomar.ef@gmail.com>.

*Corresponding author.
}

\begin{abstract}
This study aimed to analyze economically the production of wood and charcoal from a Eucalyptus plantation stratified in three classes of productivity in northwestern Minas Gerais. Were used data from not thinned Eucalyptus stands whose area was stratified in high, medium and low productivity, being described by the logistic model. The data were obtained and the economic evaluation of wood production and charcoal production was carried out. The economic evaluation was made by means of the indicators: Net present value (NPV) and internal rate of return (IRR) as a function of the prices of wood and charcoal, the yield of wood in charcoal and the transport distance of wood to the charcoal production unit. The economic viability of production of Eucalyptus wood and charcoal depends on the productive capacity of the forest stand. The viability of timber and charcoal production is sensitive to the variations in the prices of both, the yield of wood in charcoal and the transport distance from the production area to the processing unit.
\end{abstract}

Keywords: Forest projects; Forest economics; Investment analysis.

\section{ANALISE ECONÔMICA DA PRODUÇÃO DE MADEIRA E CARVÃo VEGETAL POR REFLORESTAMENTOS DE EUCAlyptuS NO NOROESTE DE MINAS GERAIS}

\begin{abstract}
RESUMO - O presente estudo teve como objetivo analisar economicamente a produção de madeira e carvão vegetal de um povoamento de Eucalyptus estratificado em três classes de produtividade no noroeste de Minas Gerais. Foram utilizados dados de povoamentos de Eucalyptus não desbastados cuja área foi estratificada em alta, média e baixa produtividade, sendo descritas pelo modelo Logístico. Obtidos os dados, realizou-se então a avaliação econômica da produção de madeira e para produção de carvão. A avaliação econômica deu-se por meio dos indicadores: valor presente líquido (VPL) e taxa interna de retorno (TIR) em função dos preços da madeira e do carvão vegetal, do rendimento da madeira em carvão e da distância de transporte da madeira até a unidade de produção de carvão. A viabilidade econômica da produção de madeira e de carvão vegetal de Eucalyptus depende da capacidade produtiva da área de instalação do povoamento. A viabilidade de produção de madeira e de carvão vegetal é sensível às variações dos preços de ambos, do rendimento da madeira em carvão e da distância de transporte da área de produção à unidade de processamento.
\end{abstract}

Palavras-Chave: Projetos florestais; Economia florestal; Análise de investimento. 


\section{INTRODUCTION}

Forestry activity requires intensive investment in land and capital, presenting low initial rates of return due to the slow growth of the forest, allowing the recovery of capital only in the long term (Noce et al., 2005), and in this way, it can be said that it is a sector of risk and strongly dependent on the consumer market.

The forestry production can be destined for different purposes, and the producer must be guided to seek the best-selling option. Among the options are the direct sale of wood, or the sale of wood products.

Charcoal is one of the products that can be obtained, and this currently contributes significantly to the development of the forestry based industries in Brazil. In Minas Gerais, most of the timber production is turned towards this use, and its price is formed in an imperfect competition market. On the demand side, there are few steel mills and on the supply side there are many independent producers (competitive) (Sablowski, 2008).

The application of economic analysis criteria becomes fundamental to subsidize investment decisions in the forestry area, guiding the choices of the best projects and, or, production alternatives (Castro et al., 2011). According to Rezende and Oliveira (2008) the economic analysis involves the use of techniques and criteria that compare the costs and revenues inherent to the projects, in order to verify whether or not should be implemented, besides allowing to choose the most interesting option.

The price of the product is decisive for the viability of the forestry project, but can only be confirmed on the date of marketing. The discount rate is also one of the variables that most affect the profitability of reforestation (Silva et al., 2007), however we cannot control it, so there is a risk in the economic viability of production.

The risk, in its fundamental sense, is the possibility of financial impairment or, more formally, the variability of returns associated with a given asset (Noce et al., 2005). There will always be uncertainties when there are no known future states that may occur and, or, their probabilities of occurrence.

Currently, there are few existing studies on financial investments in reforestation projects, which include information on the costs of the implantation, maintenance and commercialization of timber production of planted forest and its byproducts (Sanguino, 2009), as well as variations that may occur.

To minimize risk, careful estimates of data and operational costs should be obtained, as well as any other type of information necessary for evaluating the project. It is of fundamental importance to incorporate changes in the price product, as well as changes in costs susceptible to control, to evaluate the sensitivity to which the investments are subject to.

In this context, this study aimed to carry out an economic analysis of the production of wood and charcoal by a reforestation of Eucalyptus, in different conditions of productive capacity. In addition, an analysis of sensitivity was carried out in relation to the price of wood and charcoal, the production of wood in charcoal and the distance of transport from timber to the charcoal production unit, to verify the influence of these factors in the economic viability of production.

\section{MATERIAL AND METHOD}

The data used in this study refer to stands of clones and hybrids of Eucalyptus spp. not thinned belonging to a forestry company located in the northwest region of the state of Minas Gerais (17 $36^{\prime} \mathrm{S}$ and $46^{\circ} 42^{\prime} \mathrm{W}$ ), conducted for charcoal production under high forest regime. The climate of the region is the humid tropical savannah, with dry winter and rainy summer, of type Aw, according to the Köppen classification. The average annual temperature is $22.6^{\circ} \mathrm{C}$, with a monthly average of $18^{\circ} \mathrm{C}$ in the colder season and $29.1^{\circ} \mathrm{C}$ in the hottest. The average annual rainfall is $1,450 \mathrm{~mm}$, with monthly average precipitation below $60 \mathrm{~mm}$ in the driest months. The remaining vegetation consists of Brazilian savannah, represented by its various phytophysiognomies, from fields to forest formations, and riparian forests(Macedo et al., 2005).

The production area evaluated was 4,052 hectares. The plantations were conducted with a mean spacing of $3.0 \mathrm{~m} \mathrm{x} 2.0 \mathrm{~m}$. The area was initially stratified into three productivity classes (high, medium and low). The high productivity class (S31) included an area of 1,398 ha, the medium (S25) and low productivity (S19) classes, included areas of 1,230 and 1,424 ha, respectively. The growth curves in volume in each productivity class were described by the logistic model (Figure 1). 


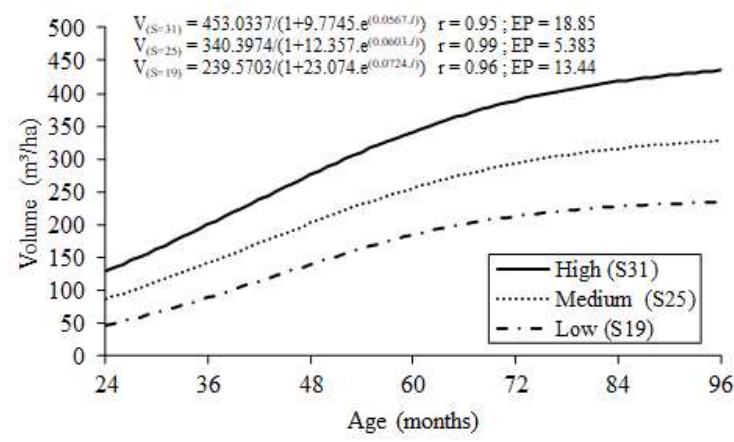

Figure 1 - Production curves for the areas of High (S31), Medium (S25) and Low (S19) productive capacity in Eucalyptus reforestation in the northwest of Minas Gerais. $\mathrm{EP}=\mathrm{a}$ standard error of estimation.

Figura 1 - Curvas de produção para as áreas de Alta (S31), Média (S25) e Baixa (S19) capacidade produtiva, na região Noroeste de Minas Gerais. EP é o erro padrão da estimativa.

The costs of the operations considered in this study are described in Table 1. This information was provided by the technicians of the company, responsible for the implantation and conduction of the stands. The cost of the land factor was considered by the method of interest on the value of the land, because, according to Silva et al. (2008) provides more consistent results with market values.

The economic evaluation of wood production was carried out until the time of cutting and stacking of wood in the field. For charcoal production, the transport of timber to the charcoal production/processing unit (UPC) was also considered, as well as the costs for converting timber into charcoal (Table 1).

The costs of transporting timber to the UPC were calculated according to Silva et al. (2007):

$$
C T=\frac{P f}{C a p} * 2 D * P
$$

Where: $\mathrm{CT}$ is the transporting cost $(\mathrm{R} \$)$; $\mathrm{Pf}$ is the indicative factor of the price of the freight on the market per $\mathrm{km}(\mathrm{R} \$ 2.70 / \mathrm{km})$; Cap is the capacity of the truck load $\left(41 \mathrm{~m}^{3}\right)$; D is the distance that is multiplied by 2 , which considers the round trip (average of 50 $\mathrm{km})$ and $\mathrm{P}$ is the production of $\operatorname{wood}\left(\mathrm{m}^{3} / \mathrm{ha}\right)$.

To evaluate the economic viability of wood and charcoal production, two methods were used: Net Present Value (NPV) and Internal Rate of Return
(IRR), defined according to Rezende and Oliveira (2008):

- NPV: Algebraic sum of the discounted values of the cash flow associated with it, that is, the difference in the present value of the revenues minus the present value of the costs. The essential characteristic of the NPV method is the discount, for the present, of all expected cash flows as a result of an investment decision. Its formula is given by:

$$
N P V=\sum_{j=0}^{n} R_{j}(1+i)^{-j}-\sum_{j=0}^{n} C_{j}(1+i)^{-j}
$$

In which: $\mathrm{Rj}=$ Current value of revenues; $\mathrm{Cj}=$ current value of costs; $i=$ interest rate; $j=$ period in which the revenues or costs occur; and number of periods or duration of the project.

- IRR: The discount rate that equals the current value of the revenues to the current value of the costs. It can be understood as the average growth rate of an investment. The IRR value of a project indicates the percentage return that the project yields under the invested capital. It can be used to compare projects of the same duration and magnitude, according to the formula below:

$$
\sum_{j=0}^{n} R_{j}(1+I R R)^{-j}=\sum_{j=0}^{n} C_{j}(1+I R R)^{-j}
$$

In which: $\mathrm{Rj}=$ Current value of revenues; $\mathrm{Cj}=$ current value of costs; $j=$ period in which the revenues or costs occur; and $n=$ number of periods or duration of the project.

A project is considered economically viable if the NPV values are positive, indicating that revenues are higher than the costs. When comparing two or more projects, it will be the most economically viable one that presents the highest values by this criterion.

In order to verify the economic viability of projects using IRR, it should be considered that, being the IRR an average growth rate of the project, this will be viable if its value is greater than or equal to the rate of remuneration of capital, usually known by Minimum Attractiveness Rate (MAR), which is the rate used in financial applications such as savings, etc. In this study, the MAR was considered as $8.0 \%$ (Silva et al., 2007).

After evaluating the NPV and IRR indicators, an economic feasibility was carried out based on the wood 
Table 1 - Data used in the economic analysis of timber production management and charcoal by reforestation of Eucalyptus in the northwest of Minas Gerais.

Tabela 1 - Dados utilizados na análise econômica do manejo da produção de madeira e carvão vegetal por reflorestamento de eucalipto no noroeste de Minas Gerais.

\begin{tabular}{|c|c|c|c|}
\hline Year & Activity / Input & Value & Unid \\
\hline$\overline{0}$ & Ant control & 110.00 & $\mathrm{R} \$ / \mathrm{ha}$ \\
\hline 0 & Mechanical mowing in total area & 50.00 & $\mathrm{R} \$ / \mathrm{ha}$ \\
\hline 0 & Application of limestone in total area & 35.00 & $\mathrm{R} \$ / \mathrm{ha}$ \\
\hline 0 & Herbicide application in total area & 35.00 & $\mathrm{R} \$ / \mathrm{ha}$ \\
\hline 0 & Harrowing on the subsoiling line & 45.00 & $\mathrm{R} \$ / \mathrm{ha}$ \\
\hline 0 & Subsoiling with phosphating & 150.00 & $\mathrm{R} \$ / \mathrm{ha}$ \\
\hline 0 & Planting & 90.00 & $\mathrm{R} \$ / \mathrm{ha}$ \\
\hline 0 & Replanting & 30.00 & $\mathrm{R} \$ / \mathrm{ha}$ \\
\hline 0 & Manual fertilizing (NPK) & 80.00 & $\mathrm{R} \$ / \mathrm{ha}$ \\
\hline 0 & Chemical control of intra-row weed & 100.00 & $\mathrm{R} \$ / \mathrm{ha}$ \\
\hline 0 & Seedling transport to the field & 15.00 & $\mathrm{R} \$ / \mathrm{ha}$ \\
\hline 0 & Intra-row sprout thinning with hoe & 90.00 & $\mathrm{R} \$ / \mathrm{ha}$ \\
\hline 0 & Inter-row mechanical mowing & 45.00 & $\mathrm{R} \$ / \mathrm{ha}$ \\
\hline 0 & Inter-row herbicide application & 45.00 & $\mathrm{R} \$ / \mathrm{ha}$ \\
\hline 0 & Intra-row herbicide application (costal sprayer) & 100.00 & $\mathrm{R} \$ / \mathrm{ha}$ \\
\hline 0 & Maintenance of seedling deposit & 10.00 & $\mathrm{R} \$ / \mathrm{ha}$ \\
\hline 0 & Top-dressing fertilization (90 days, manual) & 80.00 & $\mathrm{R} \$ / \mathrm{ha}$ \\
\hline 0 & Irrigation $(1 \mathrm{x})$ & 120.00 & $\mathrm{R} \$ / \mathrm{ha}$ \\
\hline 0 & Fertilizer NPK 06-30-06 + micros & 150.00 & $\mathrm{R} \$ / \mathrm{ha}$ \\
\hline 0 & Reactive phosphate & 301.00 & $\mathrm{R} \$ / \mathrm{ha}$ \\
\hline 0 & Termiticide & 35.00 & $\mathrm{R} \$ / \mathrm{ha}$ \\
\hline 0 & Formicidal bait & 65.00 & $\mathrm{R} \$ / \mathrm{ha}$ \\
\hline 0 & Powdered formicide & 3.00 & $\mathrm{R} \$ / \mathrm{ha}$ \\
\hline 0 & Herbicide & 72.00 & $\mathrm{R} \$ / \mathrm{ha}$ \\
\hline 0 & Pre-emergent herbicide & 50.00 & $\mathrm{R} \$ / \mathrm{ha}$ \\
\hline 0 & Soil conditioner (gel) & 30.00 & $\mathrm{R} \$ / \mathrm{ha}$ \\
\hline 0 & Fertilizer NPK 20-00-20 + micros & 216.00 & $\mathrm{R} \$ / \mathrm{ha}$ \\
\hline 0 & Clonal seedlings & 437.50 & $\mathrm{R} \$ / \mathrm{ha}$ \\
\hline Subtotal Year 0 & (1) & 2589.50 & $\mathrm{R} \$ / \mathrm{ha}$ \\
\hline 1 & Herbicide + Fertilizer + Formicide + Labor + Firebreaks $* * * *$ & 550.00 & $\mathrm{R} \$ / \mathrm{ha}$ \\
\hline Subtotal Year 1 & (2) & 550.00 & $\mathrm{R} \$ / \mathrm{ha}$ \\
\hline 2 & Herbicide + Fertilizer + Formicide + Labor + Firebreaks $* *$ & 350.00 & $\mathrm{R} \$ / \mathrm{ha}$ \\
\hline Subtotal Year 2 & (2) & 350.00 & $\mathrm{R} \$ / \mathrm{ha}$ \\
\hline 3 & Formicide + Labor + Firebreaks $* *$ & 100.00 & $\mathrm{R} \$ / \mathrm{ha}$ \\
\hline Subtotal Year 3 &  & 100.00 & $\mathrm{R} \$ / \mathrm{ha}$ \\
\hline 4 & Formicide + Labor + Firebreaks $* *$ & 100.00 & $\mathrm{R} \$ / \mathrm{ha}$ \\
\hline Subtotal Year 4 & (1) & 100.00 & $\mathrm{R} \$ / \mathrm{ha}$ \\
\hline 5 & Formicide + Labor + Firebreaks $* *$ & 100.00 & $\mathrm{R} \$ / \mathrm{ha}$ \\
\hline Subtotal Year 5 & (1) & 100.00 & $\mathrm{R} \$ / \mathrm{ha}$ \\
\hline 6 & Formicide + Labor + Firebreaks $* *$ & 100.00 & $\mathrm{R} \$ / \mathrm{ha}$ \\
\hline Subtotal Year 6 & ㄱ... & 100.00 & $\mathrm{R} \$ / \mathrm{ha}$ \\
\hline 1 a 6 & Land & 224.00 & $\mathrm{R} \$ / \mathrm{ha}$ \\
\hline 1 a 6 & Administration & 80.00 & $\mathrm{R} \$ / \mathrm{ha}$ \\
\hline 0 e 6 & Licenses, fees & 100.00 & $\mathrm{R} \$ / \mathrm{ha}$ \\
\hline 6 & Pre-harvest mowing & 90.00 & $\mathrm{R} \$ / \mathrm{ha}$ \\
\hline 6 & Harvesting and extraction & 19.00 & $\mathrm{R} \$ / \mathrm{m}^{3}$ \\
\hline Interest rate & (n) & $8 \%$ & \\
\hline Price of Wood * & ㄱ... & 55 & $\mathrm{R} \$ / \mathrm{m}^{3}$ \\
\hline Cost of processing (charcoal) & (1) & 8,00 & $\mathrm{R} \$ / \mathrm{m}^{3}$ \\
\hline Charcoal yield $* * *$ & …… & 1,75 & $\mathrm{~m}^{3} / \mathrm{mdc}$ \\
\hline Price of charcoal. & (1) & 180 & $\mathrm{R} \$ / \mathrm{mdc}$ \\
\hline
\end{tabular}

*cut and piled; ${ }^{*}$ Conservation of firebreaks; $* * * \mathrm{~m}^{3}$ wood in charcoal meter $(\mathrm{mdc})$.

Revista Árvore 2019;43(1):e430110 
and charcoal prices, the wood-to-charcoal conversion rate and wood transportation distance from stands to UPC. In the sensibility analysis of each variable, the others were remained fixed (in mean values). The wood prices used were: $\mathrm{R} \$ 45.00 ; \mathrm{R} \$ 50.00 ; \mathrm{R} \$ 55.00$ and $\mathrm{R} \$ 65.00$, considering the average market value equal to $\mathrm{R} \$ 55.00$. The charcoal prices were: $\mathrm{R} \$ 150.00$; $\mathrm{R} \$ 165.00 ; \mathrm{R} \$ 180.00 ; \mathrm{R} \$ 195.00$ and $\mathrm{R} \$ 210.00$, with the average market value equal to $\mathrm{R} \$ 180.00$. The distance from the field to the UPC was: 10, 25, 50, 75 and 100 $\mathrm{km}$, being used as reference value for the distance from $50 \mathrm{~km}$. The charcoal yield values considered, that is, the amount of $\mathrm{m}^{3}$ of wood needed to produce one stere of charcoal, were: $1.45 ; 1.60 ; 1.75 ; 1.90$ and 2.05 . The average conidered was 1.75 .

\section{RESULTS}

The results presented in Table 2 show economic viability for the production of wood and charcoal, except for the low productive capacity class when considering the timber production. The IRR provided by charcoal production was greater than double the reference rate $(8 \%)$, regardless of the productivity class of wood production.

The high productivity class proved to be the most viable, presenting higher values of NPV and IRR for both wood and charcoal production. Even in the global NPV and IRR calculations, i.e., without stratification in productive capacity classes, wood and charcoal productions were economically viable, with NPV values and IRR higher than the reference interest rate. Considering that the interest rates used in the forestry sector are usually less than $12 \%$ p.a., such projects are attractive (Table 2).

In the comparison between the indicators for wood production and those observed for the production of charcoal, it is verified that the production of charcoal showed higher profitability, independent of the class of productive capacity, with a mean increase in IRR in the order of $15.4 \%$ and profit percentage $80.7 \%$ higher than wood production per hectare.

In the analysis of the sensibility of economic indicators as a function of the wood price, it is observed that increases of this enable forest projects. For the high productivity class, wood prices close to $\mathrm{R} \$ 45.00$ per $\mathrm{m}^{3}$ still mark the project as economically viable, with NPV positive and IRR greater than $12 \%$, whereas in the classes of medium and low productivity only make possible the production of wood, prices in values exceeding $\mathrm{R} \$ 60.00 / \mathrm{m}^{3}$ and $\mathrm{R} \$ 48,00 / \mathrm{m}^{3}$, respectively (Figure 2a, b). For the charcoal, the analysis of economic indicators as a function of the price demonstrates that production is feasible for any of the productivity classes (Figure 2c, d).

Although the distance from the production area to the UPC is more of a limiting factor in the feasibility of a project, for the production of charcoal has proved to be viable in all classes of productivity and in all distances analyzed from the timber transportation of the field to the UPC, having NPV and IRR a minimum of $\mathrm{R} \$ 3129.60$ and $18.6 \%$, respectively. It is important to highlight that the distance was considered only to the production of charcoal, because it refers to the transportation of the stands to the UPC, for wood to charcoal conversion(Figure 2e, f).

Charcoal yield considerably affected economic indicators. Although charcoal production was viable, regardless of the productivity class, there was a decrease in the NPV and IRR, of the best $\left(1.45 \mathrm{~m}^{3} /\right.$ st) for the worst yield $\left(2.05 \mathrm{~m}^{3} / \mathrm{st}\right)$. For the NPV this decrease was $52.6 \%, 58.6 \%$ and $71.0 \%$ for the classes of high, medium and low productivity, respectively. For the IRR the reductions were from $42.6 \%$ to $29.5 \%$ in the high class; $35.3 \%$ to $22.7 \%$ in the medium class; $27.3 \%$ to $15.2 \%$ in the low productivity class (Figure 2g, h).

Table 2 - Economic analysis, by productivity class and overall, of the production of wood and charcoal for reforestation of Eucalyptus in the northwest of Minas Gerais.

Tabela 2 - Análise econômica, por classe de produtividade e global, da produção de madeira e carvão vegetal por reflorestamento de eucalipto noroeste de Minas Gerais.

\begin{tabular}{llccc}
\hline Class of productivity & $N P V$ Wood & $N P V$ Charcoal & IRR Wood & IRR Charcoal \\
\hline High (S31) & $\mathrm{R} \$ 3548.11$ & $\mathrm{R} \$ 11703.29$ & $19.7 \%$ & $35.7 \%$ \\
Medium (S25) & $\mathrm{R} \$ 1377.48$ & $\mathrm{R} \$ 7526.52$ & $13.2 \%$ & $28.6 \%$ \\
Low (S19) & $-\mathrm{R} \$ 448.68$ & $\mathrm{R} \$ 4012.61$ & $6.0 \%$ & $20.9 \%$ \\
\hline Global & $\mathrm{R} \$ 1484.61$ & $\mathrm{R} \$ 7732.67$ & $13.6 \%$ & $29.0 \%$ \\
\hline
\end{tabular}


(a)
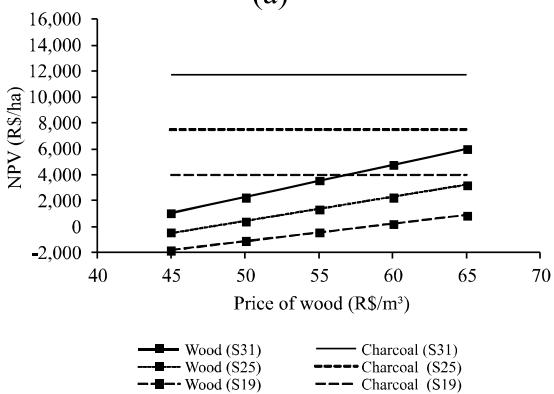

(c)

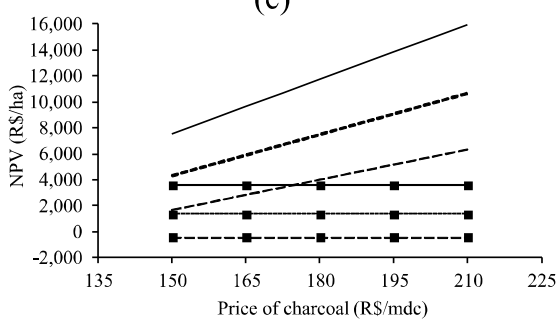

Charcoal (S31)
-Wod (S31)
--- Charcoal (S25)
-- Ch25)

(e)

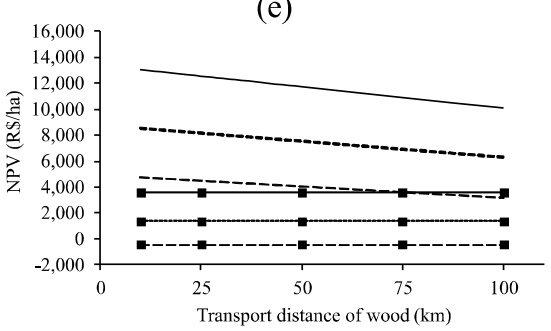

$\begin{array}{ll}\text { \#-Wood (S31) } & \text { Charcoal (S31) } \\ \text {--Wood (S25) } & \text {-- Wood (S19) }\end{array}$

(g)

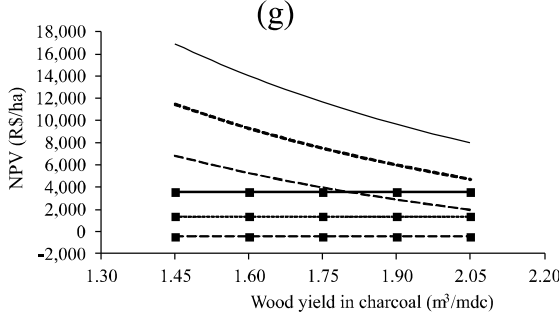

\begin{tabular}{ll}
-Wood (S31) & Charcoal (S31) \\
-- Wood (S25) & Charcoal (S25) \\
\hdashline$--\cdot$ Wood (S19) & Charcoal (S19)
\end{tabular} (b)

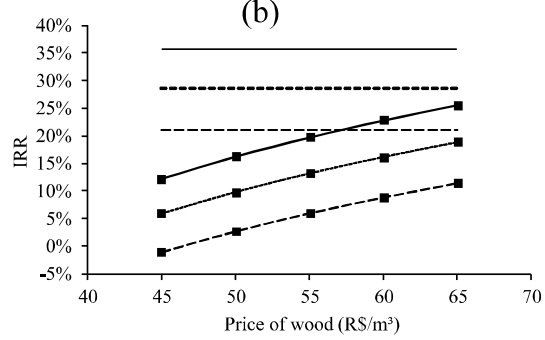

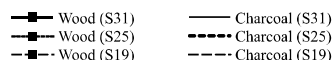

(d)

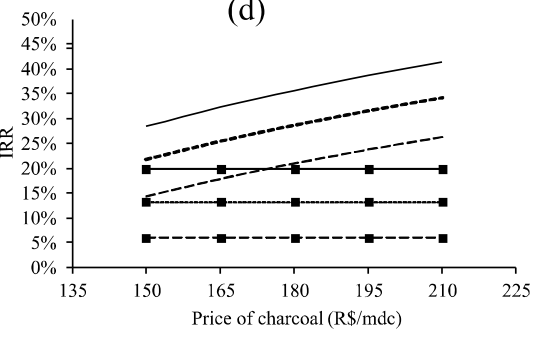

- Wood (S31)
-- Charcoal (S31)
-- - Wood (S25)
- - Charcoal (S25)
-S19)

(f)

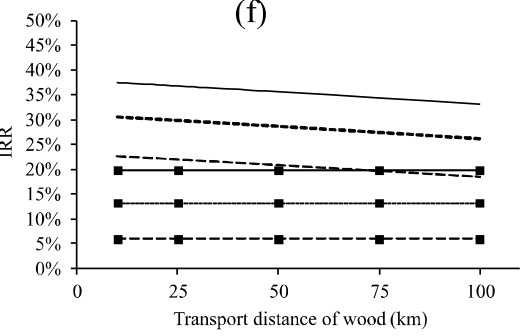

\begin{tabular}{ll}
- Charcoal (S31) \\
- Wood (S31) \\
\hdashline-- Charcoal (S25) \\
- Wood (S19)
\end{tabular}

(h)

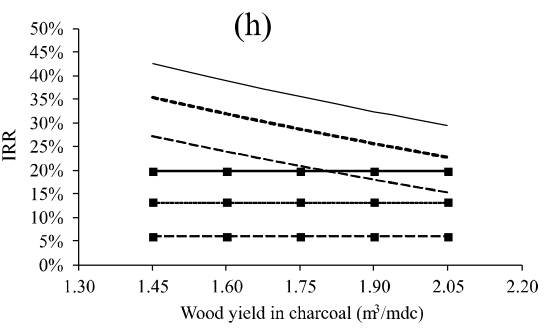

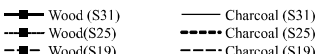

Figura 2 - Net Present Value (NPV) and Internal Rate of Return (IRR) as a function of the price of wood and charcoal, transport distance of wood of the forest to the charcoal production unit - the UPC and of wood yield in charcoal (charcoal meter - mdc), to Eucalyptus reforestation in northwest of Minas Gerais.

Figure 2 - Valor Presente Líquido (NPV) e Taxa Interna de Retorno (IRR) em função do preço da madeira e do carvão, distância de transporte de madeira da floresta para a unidade de produção de carvão vegetal - UPC e da produção de madeira em carvão vegetal (metro de carvão vegetal - mdc), para reflorestamento de Eucalyptus no noroeste de Minas Gerais.

Revista Árvore 2019;43(1):e430110 


\section{DISCUSSION}

The areas classified as high productivity stood out as to the economic indicators for the wood and charcoal production, and its necessary to consider this characteristic when the rotation the stands. In addition, this factor may influence the quality of the product obtained (Neves et al., 2011).

In Brazil, 29\% of the existing planted forests belong to independent producers and small and medium producers of the forestry promotion program that invest in forest plantations for the commercialization of natural wood, another $14 \%$ of the planted area belong to companies in the charcoal steel industry (IBÁ, 2017). Especially when referring to the first case, economic feasibility studies constitute an important part of the forestry project, mainly because the volatility of the wood and charcoal prices are difficult to estimate, because they are inputs for the production of other products.

In the conditions presented, charcoal production is always more advantageous than the commercialization of in natura wood, whose production in areas of low productive capacity is economically unfeasible. These results make more relevant the economic analysis that take into consideration production and market aspects, such as those of the present study, which can contribute to decision making. From the sensibility analysis it was verified that the variables price and transportation costs have a direct effect on the viability of the stands, and that slight alterations in these variables can prioritize the alternative of production of wood or charcoal. With regard to transport costs, it is known that this has considerable effect on the final cost of timber production, because wood is a product of low specific value, that is, with low value in relation to its weight or volume, making the transport cost of this product relatively high (Silva et al., 2007). In this way, the total production costs increase substantially with the increase in the distance traveled. Therefore, the location of the UPC in relation to reforestation is strategic decisions and requires detailed planning.

It is also important to highlight that the worsening of the yield in the conversion of wood into charcoal results in a marked reduction of NPV and IRR, which demonstrates the importance of choosing the species/clone for a particular purpose or that satisfactorily satisfies more than one use (Neves et al.,
2011; Andrade et al., 2018). In addition, the adopted production technology is also determinant in the yield obtained. Greater investment can mean higher yields and consequently better economic indicators. However, if the production costs are high, as reported by Belchior et al. (2017), and producer does not have capital for investment in charcoal production, the commercialization of in natura wood may be the safer destination if, as well as in present analysis, both situations are viable.

It is essential to carry out a thorough forest planning of all activities involved in the production process, so that it results in lower risk costs, minimization of operating costs, improvement of the productivity of the stands, etc. (Hosokawa and Mendes, 1984), in the case of independent producers. From a business standpoint, economic unfeasibility may not yet be sufficient to decide on the implementation of a reforestation. Obviously, it is necessary that companies have assurance of production and homogeneity of the product, which makes it necessary to produce wood or charcoal even under conditions of impairment, since often its production is fundamental (raw material) for the production of other products.

\section{CONCLUSIONS}

The economic viability of timber and charcoal production depends on the productive capacity of the stand.

The viability of timber and charcoal production is sensitive to the variations in the prices of both, the yield of wood in charcoal and the transport distance from the production area to the processing unit.

\section{REFERENCES}

Andrade FWC, Tomazello Filho M, Moutinho VHP. Influence of wood physical properties on charcoal from Eucalyptus spp. Floresta e Ambiente. 2018;25(3):e201501762018.

Belchior IB, Sabbag OJ, Polini DMSS, Pereira VGMF, Pacheco A. Custos e viabilidade econômica na produção de carvão vegetal no estado de Mato Grosso do Sul. Brazilian Journal of Wood Science. 2017;8(3):168-76.

Castro RVO, Leite HG, Nogueira GS, Soares CPB, Araújo Júnior CA, Castro AFNM, et al. Avaliação

Revista Árvore 2019;43(1):e430110 
econômica de um povoamento de eucalipto desbastado e destinado a multiprodutos da madeira. Scientia Forestalis, 2011;39:351-7.

Hosokawa RT, Mendes JB. Planejamento florestal: técnicas para a manutenção da contribuição do setor florestal à economia nacional. Revista Floresta. $1984 ; 15(1 / 2): 4-7$.

Indústria Brasileira de Árvores - IBÁ. Anuário Estatístico IBÁ 2017. Brasília, DF: 2017.

Macedo RLG, Gomes JE, Venturin N, Salgado BG. Desenvolvimento inicial de Tectona grandis L.f. (TECA) em diferentes espaçamentos no município de Paracatu, MG. Revista Cerne. 2005;11(1):61-9.

Neves TA, Protásio TP, Couto AM, Trugilho PF, Silva VO, Vieira CMM. Avaliação de clones de Eucalyptus em diferentes locais visando à produção de carvão vegetal. Pesquisa Florestal Brasileira. 2011;31(68):319-30.

Noce R, Silva ML, Soares TS, Carvalho RMMA. Análise de risco e retorno do setor florestal: produtos da madeira. Revista Árvore.
$2005 ; 29(1): 77-84$.

Rezende JLP, Oliveira AD. Análise econômica e social de projetos florestais. $2^{\mathrm{a}}$.ed. Viçosa, $\mathrm{MG}$ : UFV; 2008. 386p.

Sablowski ARM. Balanço de materiais na gestão ambiental da cadeia produtiva do carvão vegetal para produção de ferro gusa em Minas Gerais [tese]. Brasília, DF: Universidade de Brasília; 2008.

Sanguino AC. Custos de implantação e rentabilidade econômica de povoamentos florestais com Teca no Estado do Pará. Revista de Ciências Agrárias. 2009(52):61-78.

Silva ML, Oliveira RJ, Valverde SR, Machado CC, Pires VAV. Análise do custo e do raio econômico de transporte de madeira em reflorestamentos para diferentes tipos de veículos. Revista Árvore. 2007;31(6):1073-9.

Silva ML, Resende JLP, Lima Junior VB, Cordeiro AS, Coelho Junior LM. Métodos do cálculo de custo da terra na atividade florestal. Revista Cerne. 2008;14(1):75-81. 